\title{
NORTH AMERICA'S OLDEST GREAT HORNED OWL
}

C. STUART HOUSTON, 863 University Drive, Saskatoon, Saskatchewan. S7N $0 J 8$

From 4,651 flightless Great Illinois, that was found freshly dead Horned Owls banded through 1987 , there have been many interesting recoveries. For four years, one of these held the record longevity in the wild for a banded Great Horned Owl - 13 years, 6 months. I had banded this owl in a nest found by Bill Horseman at Bredenbury, Saskatchewan, on 17 May 1959. It was caught in a trap at Roblin, Manitoba, on 4 December 1972. The longevity record was next surpassed by an owl banded by $D$. Seal of Rockford, not far away, 17 years and four months after banding.

Among the 262 nestling Great Horned Owls I banded in 1967, a "build-up" year in the ten-year cycle of the Snowshoe Hare, there have been some remarkable longevity records. Of my 367 recoveries from Great Horned Owls banded in Saskatchewan, 169 occurred in the first eight months, and 213 in the first year (Houston and Francis, mss.);

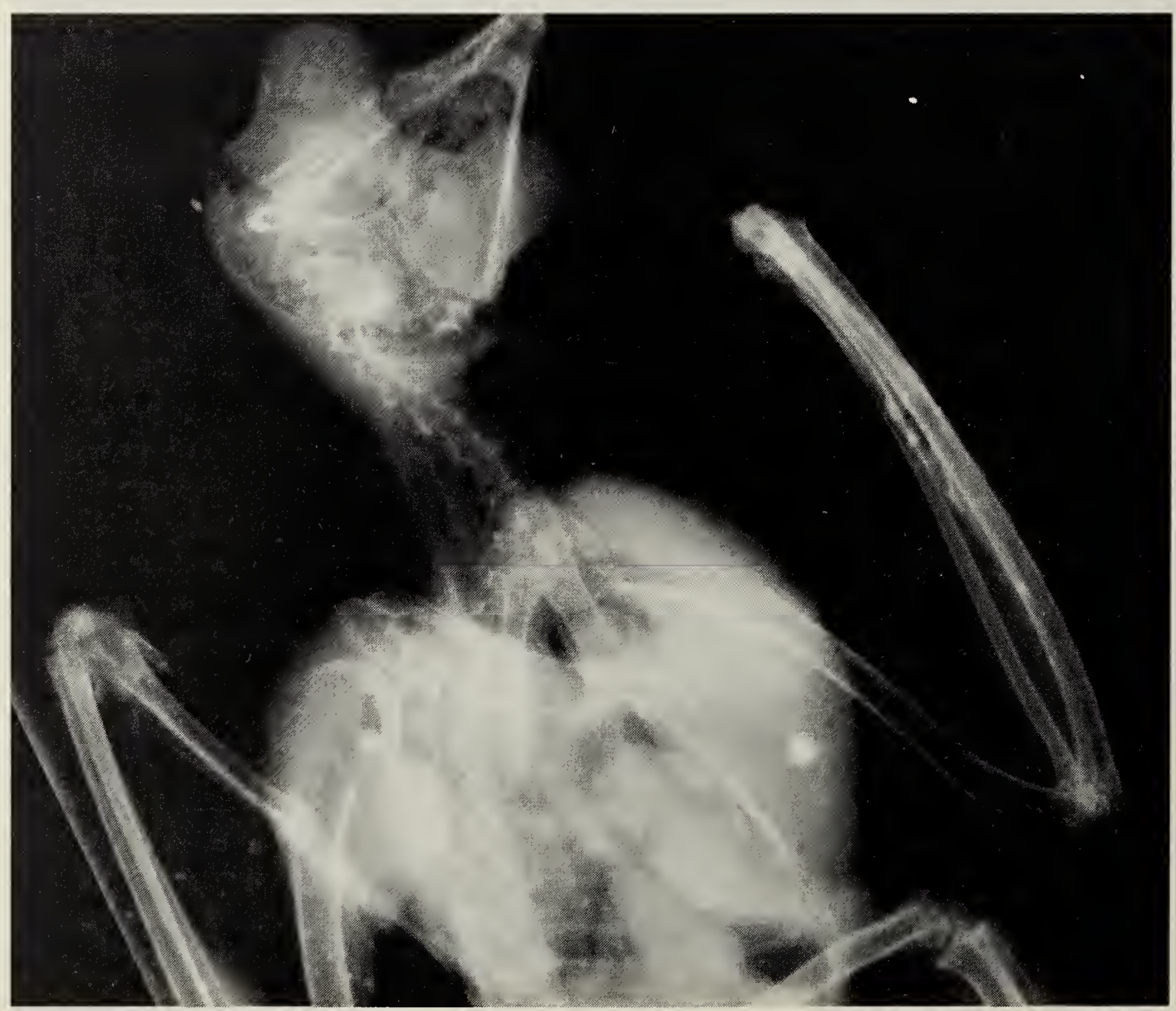

Figure 1. Radiograph of owl skeleton. 


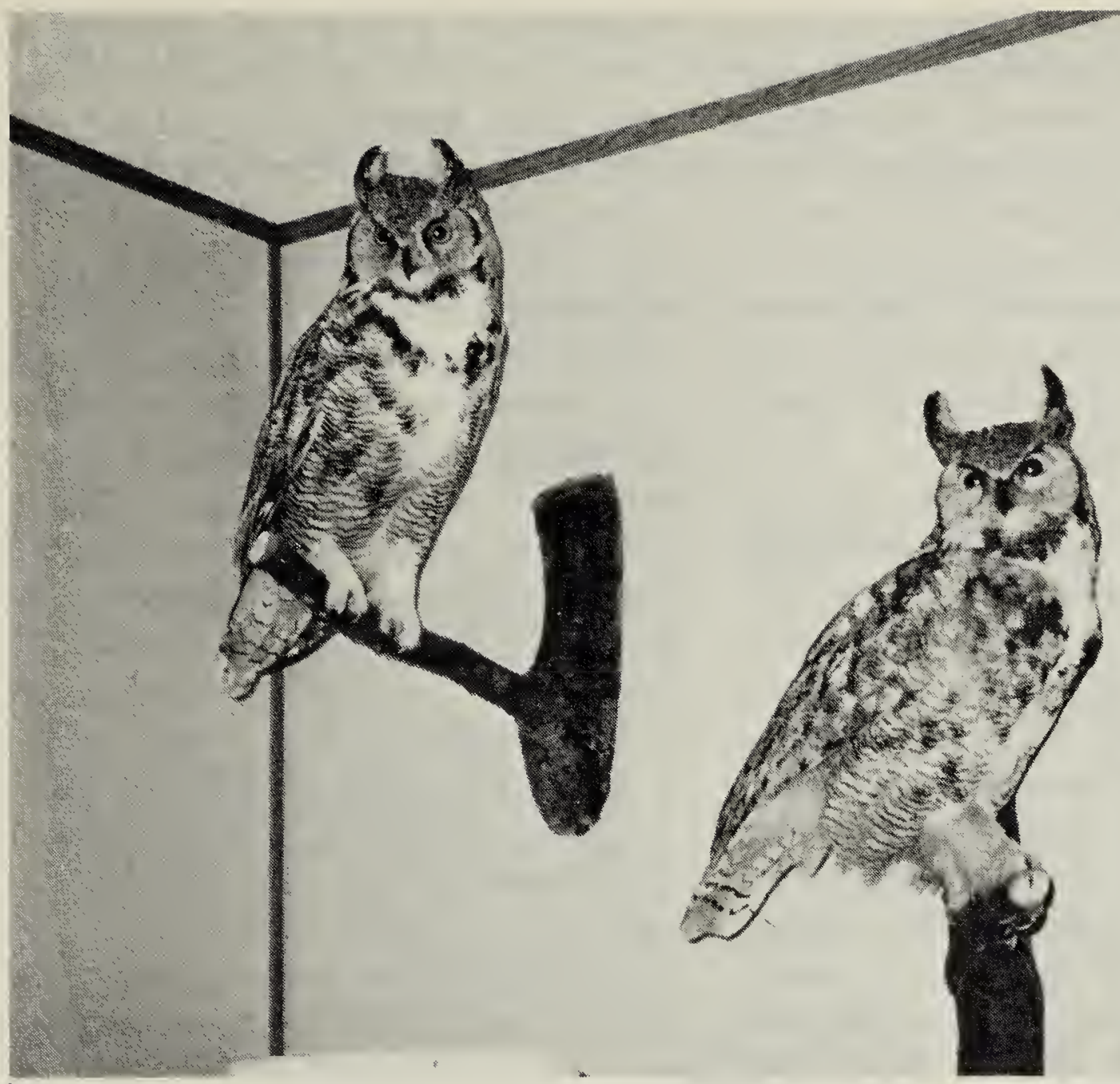

Figure 2. Hal Fleischhaker's mounted owls.

Mary Houston

1967 has provided more longterm survivors than any other banding year to date. This included one owl each at $5,6,7,9,16$, and 17 years of age. The owl banded with tag 51860395 was banded near St. Benedict on 14 May 1967 and was hit by a motor vehicle near Hendon on 30 July 1983, when 16 years, 2 months old. Another owl (518-60341) had been banded in its nest near Saskatoon 10 May 1967 and found freshly dead near Delisle, Saskatchewan, 17 June 1984, when 17 years, 1 month old. ${ }^{1}$

The longest survivor was 518 . 60626 , one of two nestlings in a nest built a year or more earlier by a Redtailed Hawk, 29 feet above the ground in a Trembling Aspen on the southwest quarter of Section 17, Township 35, Range 1, west of the 3rd Meridian, west of Elstow. This location is entered in the banding computer on the Patuxent Refuge at
Laurel, Maryland, near Washington, D.C. The nest was found by Jon Gerrard, a keen university student, now a medical researcher at the University of Manitoba and co-author of Bald Eagle: haunts and habits of a wilderness monarch published by Western Producer Prairie Books, Saskatoon, in 1988. When Jon and I visited the nest it contained a Northern Pocket Gopher as uneaten food and one addled owl egg.

The owl 518-60626 was 20 years, 8 months old when it was killed by a truck on Highway $5,9 \mathrm{mi}$ east of Highway 41. I contacted the finder, Hal Fleischhaker of Humboldt, and learned the exact location of its demise, where an entry lane joined the highway in the southeast quarter of Section 2, Township 37, Range 3, west of the 3rd meridian. This is in the quadrant 520-1061, named "South of Aberdeen, Saskatchewan." The owl was in such fine shape that 
Hal took it to conservation officer $\mathrm{J}$. Ray Little in Humboldt, to receive a permit to get it mounted. Hal had to prove that the owl had not been shot. The local veterinarian took a radiograph of the owl skeleton (Figure 1). Later the bird was mounted. My wife, Mary, took this photo of Hal's two mounted owls in his home six miles north of Humboldt (Figure 2).

For about two years this owl held the record longevity for North America, and was so acknowledged in a compilation of longevity records published in 1989. ${ }^{2}$ Unfortunately, through an error in reading an adjacent line on the computer printout, this citation cited the banding location incorrectly as "Lanigan, Sas- katchewan." The record was soon eclipsed by two even older owls from New York state and then far exceeded by the Manitoba owl reported in this issue by R.W. Nero. These long-lived owls are rare exceptions, but after I cease my full-scale owl banding after the 1992 season, I can look forward to occasional recovery records for at least another 20 years to come.

1. HOUSTON, C.S. 1985. Longevity of Saskatchewan birds. North American Bird Bander 10:66-67.

2. KLIMKIEWICZ, M.K. and A.G. FUTCHER. 1989. Longevity records of North American birds. Supplement No. 1. J. of Field Ornithol. 60: 469-494.

All these cattle are of one color, namely brown, and it was a great marvel to see a white bull in such a multitude. Their form is so frightful that one can only infer that they are a mixture of different animals. The bulls and cows alike are humped, the curvature extending the whole length of the back and even over the shoulders. And although the entire body is covered with wool, on the hump, from the middle of the body to the head, the breast, and the forelegs, to just above the knee, the wool is much thicker, and so fine and soft that it could be spun and woven like that of Castilian sheep. It is a very savage animal, and is comparably larger than our cattle, although it looks small because of its short legs. its hide is the thickness of that of our cattle, and the native indians are so expert in dressing the hides that they convert them into clothing. Don Juan de Onate. 1601. True account of the Expedition of Onate Toward the East. 